\title{
Policy options for improved forest use by smallholders in the Ecuadorian Amazon
}

\author{
Elena Mejía, Pablo Pacheco, Alfredo Carrasco, Ayme Muzo and Bolier Torres
}

\section{Key points}

- The Forest Law Enforcement, Governance and Trade (FLEGT) Action Plan, launched in 2003, is the European Union's (EU) response to the global fight against illegal logging. In particular, FLEGT aims at reducing trade in illegal timber between the EU and timber producer partner countries.

- FLEGT operates through two major instruments: bilateral trade agreements - known as voluntary partnership agreements (VPAs) - that are signed with willing producer countries, and the European Union Timber Regulation (EUTR), which came into force in March 2013. The EUTR mandates EU importers to exert due diligence in their sourcing of timber from abroad to exclude illegal supplies.

- To date, six countries have signed VPAs. Among them, five have committed to apply VPA provisions regarding legality verification not only to timber imported to Europe, but also to timber traded on the domestic market in signatory producer countries. This means that timber harvested and traded on the domestic market will be regulated by national VPA licensing schemes (the so-called Timber Legality Assurance System, TLAS).

- Ecuador has made significant efforts in recent years to improve governance conditions in the forest sector by redefining the role of State agencies, adjusting forestry regulations and improving the monitoring system for legal compliance. The Ecuadorian government decided not to pursue the negotiation of a VPA with the EU, thus most of these reforms are nationally-led initiatives.

- Monitoring of legal timber extraction is complemented by payments for conservation and incentives for forest regeneration and timber plantations. Ecuador has made significant efforts to improve governance conditions in the domestic timber sector, specifically by simplifying the forestry regulations, allowing the use of simplified permits, and by implementing a robust and relatively sophisticated system for verification of forest legality, accompanied by controls at the different stages of the timber chain. Yet, there is scope for improvement in better integrating smallholders into the timber market.

- Policy actions should focus on improving monitoring of 'downstream' activities in the value chain (e.g. depots, sawmills, industries); enhancing the monetary and non-monetary incentives for forest management and restoration in individual landholdings and community lands; improving information on timber prices and markets; and facilitating more transparent contracts between different actors.

- Most timber harvesting in the Ecuadorian Amazon is done with chain saws on small-scale landholdings or indigenous community lands, and a portion of it is extracted without permits. Yet, most of the timber is legalized when it reaches the urban markets. Most timber is traded by intermediaries who have significant control of the markets. These actors have important access to capital, networks and technical know-how.

- Smallholders selling timber can earn more money when they undertake the logging through approved management plans, as long as they participate in the sawing, harvest valuable species and engage directly in the selling of their timber with local intermediaries. Type of species and participation in the harvesting are far more crucial factors than legality in income generation, although legal wood often fetches better prices in the market.

\section{Background}

In the past, forest governance in Ecuador primarily relied on forest control, this began to change in 2008 when the incentive program Forest Partner (Socio Bosque) was started, and in 2011 when the Forest Administration System (Sistema de Administración Forestal, SAF) began. During 2000-2006, the governance model was characterized by outsourcing of the monitoring system to third parties, and decentralization of some functions of the Ministry of Environment (Ministerio del Ambiente, MAE) to local governments. In 2007, the MAE acknowledged that these strategies had resulted in weak institutions, and failed to address the existing problems related to forest management and control, so the ministry reclaimed these responsibilities. 
The forestry sector in Ecuador includes plantations, agroforestry systems and native forests. Most timber for industrial purposes originates in timber plantations in the coastal and highland regions. Demand for timber is dictated by the main urban centers, which consume timber originating from the coast, highland and Amazon regions. The main timber sources are plantations and agroforestry systems, followed by pioneer species and native forests.

The Amazon region alone provides about $12 \%$ of total timber production. About $46 \%$ of wood originates from native forests, and $81 \%$ from small-scale operations. Most timber in the Amazon is harvested with chain saws on small-scale landholdings or indigenous community lands. Research data from native forests suggests that in 2011 informal logging accounted for 60,000-76,000 m³ (Mejía and Pacheco 2014). A significant amount of timber harvested is not covered by any forest regulations, which has various implications for the livelihoods of small producers and for the forest economy.

The MAE has tried to address the needs of smallholders through control and incentive systems. Forestry regulations have been simplified, allowing smallholders to formulate much simpler inventories and harvesting plans compared to those made by large-scale logging operations. This favors smallscale timber management and the issue of permits with lower bureaucratic costs. In spite of these efforts, however, informality still persists in the forestry sector in Ecuador.
Ecuador has shown an interest in negotiating a VPA in the past, but the current government expressed its lack of interest in this mechanism, stressing that efforts for enhancing legal timber supply should first rely on national initiatives. Ecuador has developed an innovative system, known as the Forest Administration System (Sistema de Administración Forestal, SAF), to monitor timber supplies. SAF seeks to better organize the issue of permits and to trace timber from origin to destination at the national level. This allows tracking of demand in the main urban cities (Quito, Guayaquil and (uenca).

\section{What explains the persistence of illegal logging?}

Illegal logging has long been an issue of concern in the national debate, sometimes confused with informal logging. Some sources estimate that $60-80 \%$ of logging is conducted illegally in Ecuador (Palacios 2008; Palacios and Malessa 2010). Yet, despite these estimates, whose accuracy is uncertain, it is impossible to determine the proportion of illegal timber that reaches the market since several mechanisms are used to 'launder' timber (see Box 1). These mechanisms are used to avoid the long time required for permit approval, and meet the immediate demand for timber in urban centers.

\section{Table 1. Selected information on the timber sector in Ecuador.}

\begin{tabular}{|c|c|}
\hline Domestic consumption — in $\mathrm{m}^{3}$ RWE (average 2007-2011)a & $2,679,000$ \\
\hline Imports (average 2008-2012) (USD million) ${ }^{\mathrm{b}}$ & 49.4 \\
\hline Exports (average 2008-2012) (USD million) ${ }^{\mathrm{b}}$ & 196.9 \\
\hline $\begin{array}{l}\text { Industrial sawmill scraps (sold on the domestic market) (average 2008-2012) } \\
\text { (USD million) }\end{array}$ & 2.4 \\
\hline Production - native forest $\mathrm{m}^{3}$ (average 2007-2011) & $200-500$ \\
\hline $\begin{array}{l}\text { Profits per } \mathrm{m}^{3} \text { RWE of timber harvested } \\
(\text { USD million)c }\end{array}$ & 9.4-247 \\
\hline Profit margins (percentage) ${ }^{d}$ & $10-250$ \\
\hline $\begin{array}{l}\text { Percentage of forestry operations carried out by smallholders without an approved forest management plan in Napo } \\
\text { and Orellana provinces }\end{array}$ & 70 \\
\hline $\begin{array}{l}\text { Percentage of income from timber extraction out of total household income by smallholders in Napo and Orellana } \\
\text { provinces }^{f}\end{array}$ & 16 \\
\hline Percentage of rural households that receive income as chain-saw operators in Napo and Orellana provinces ${ }^{f}$ & 20 \\
\hline \multicolumn{2}{|l|}{ RWE $=$ roundwood equivalent. } \\
\hline \multicolumn{2}{|l|}{ a Forest Administration System (SAF), Ministry of Environment data (2011). } \\
\hline \multicolumn{2}{|l|}{ b Ecuadorian Central Bank data (2012). } \\
\hline \multicolumn{2}{|l|}{ c Information from fieldwork conducted in selected locations in Orellana and Tena provinces in May-October 2012.} \\
\hline \multicolumn{2}{|c|}{$\begin{array}{l}\text { ¿ Profit margin information was obtained from average costs of equipment, labor, transport and various authorizations, and data from net selling prices. The significant } \\
\text { range is because the values represent profits from different species, and high-value species result in higher profits. }\end{array}$} \\
\hline $\begin{array}{l}\text { e Estimated based on interviews with } 129 \text { households that carried out forestry operations _interviewed during August } 2011 \text { to September } 2012 \text { in } \\
\text { and February } 2011 \text { to July } 2012 \text { in Orellana Province. }\end{array}$ & rovince \\
\hline
\end{tabular}




\section{Box 1. Timber 'laundering' in the Ecuadorian Amazon}

Timber laundering refers to the process of legalization of informal timber through a network of actors who have the capacity and flexibility to handle small volumes of timber. There are two kinds of laundering: the first, 'more formal', is carried out around areas where legal exploitation is authorized within harvesting plans or programs. It occurs when the intermediaries purchase timber from plots that are adjacent to those authorized for formal logging. The second, possibly more frequent, involves timber that is obtained informally, 'at the edge of the road' or 'at the edge of the river'. The timber that is laundered according to the second method is mobilized through an extensive network of small depots and sawmills established within communities or on the outskirts of Amazon cities. Generally, the timber is transported by small transportation intermediaries and sold to depots, sawmills or carpentry workshops who transform the pieces into intermediate products for construction or final products, such as furniture and fruit boxes. The processed timber is subsequently transferred with a purchase receipt to other depots, sawmills or stores where it is sold to the final consumer. This activity provides the smallholders with quite a lot of flexibility in terms of the volumes to be extracted.

Pro-Formal findings show that informal markets (i.e. with no documentation supporting any of the steps from access to consumption) are common in the Amazon region close to the urban centers where final consumption occurs. In most other cases, the timber is transported to more distant urban centers, often with legal transport permits, some of which are obtained through illegal means such as bribes. These strategies guarantee the delivery of purchase orders for final buyers in the cities, which are sold with formal legal permits. Although bribes or illegal payments are relatively frequent, intermediaries said that they do not like the practice since it turns into a habit for those who are paid, thus promoting local corruption networks. Other timber is informally traded in local markets, with no legal backing and that evades payment of taxes. Based on data collected in Napo and Orellana provinces, the amount of unpaid tax represented by informally traded timber is estimated at USD 180,000-228,000 a year.
Findings from a survey of 246 smallholders undertaking smallscale harvesting operations and chain-saw milling, carried out in the provinces of Napo and Orellana in the Ecuadorian Amazon, suggest that about $70 \%$ of farmers informally sold small volumes of timber to local middlemen throughout the year. These operations are often not included in the SAF. Thus, transactions between smallholders and middlemen can be formal or informal, which normally depends on the volumes of timber, the species and the end market.

\section{Demand cannot be completely supplied by legal timber}

Total demand is estimated as the amount of timber extracted since a more accurate figure is not available. In this sense, in 2007-2012, over 2 million $\mathrm{m}^{3}$ per year were traded. In the Amazon, average legal roundwood timber extraction equates to $400,000 \mathrm{~m}^{3}$ a year. However, it seems that demand surpasses any legal supply, which constitutes the main incentive to establish informal intermediation networks to supply depots or sawmills in the cities.

Large depots in cities (Quito, Guayaquil and Cuenca) are the main timber supplier to industry, which is the largest buyer (Table 2). This suggests that greater efforts have to be invested in monitoring 'downstream' activities in the value chain (e.g. depots, sawmills, industries). In addition, timber depots and larger scale industry should bear part of the responsibility for formalizing the operations of their suppliers and be accountable for sustainable forest practices. This responsibility is most likely to be accepted by large buyers if there are options for efficient supply of timber, as long as it does not create a perverse mechanism (i.e. these buyers are the only ones monitored because they are formally accountable).

Beyond local and national demand some trans-boundary trade takes place between the Ecuadorian market and other markets, particularly on the southern border with Peru. This timber is often smuggled without complying with export requirements. Ecuadorian timber is often consumed in the northern part of Peru in urban centers, where it is sold at competitive prices compared to timber originating in Peru. There is a need for monitoring and control of timber flows in border markets, and coordinated legal assistance with neighboring countries as part of regional agreements and law enforcement.

Table 2. Type of buyer for timber originating in the Amazon (2011)

\begin{tabular}{lccccccccc}
\hline & \multicolumn{9}{c}{ Buyers } \\
\cline { 2 - 10 } & Depot & Industry & Sawmills & Furniture stores & Carpentry workshops & Not identified & Other $^{\mathrm{a}}$ & Total $^{2}$ \\
\hline $1000 \mathrm{~m}^{3}$ & 81.9 & 41.5 & 34.7 & 21.3 & 39.6 & 15.2 & 12.0 & 246.2 \\
\hline$\%$ & 33.3 & 16.9 & 14.1 & 8.7 & 16.1 & 6.2 & 4.9 & 100.0 \\
\hline
\end{tabular}

a This group comprises all those not associated with timber, building, food, agriculture, carpentry, industry, hardware, mining and fishing.

Source: Authors' elaboration based on data from the Forest Administration System (SAF), Ministry of Environment of Ecuador (2011). 


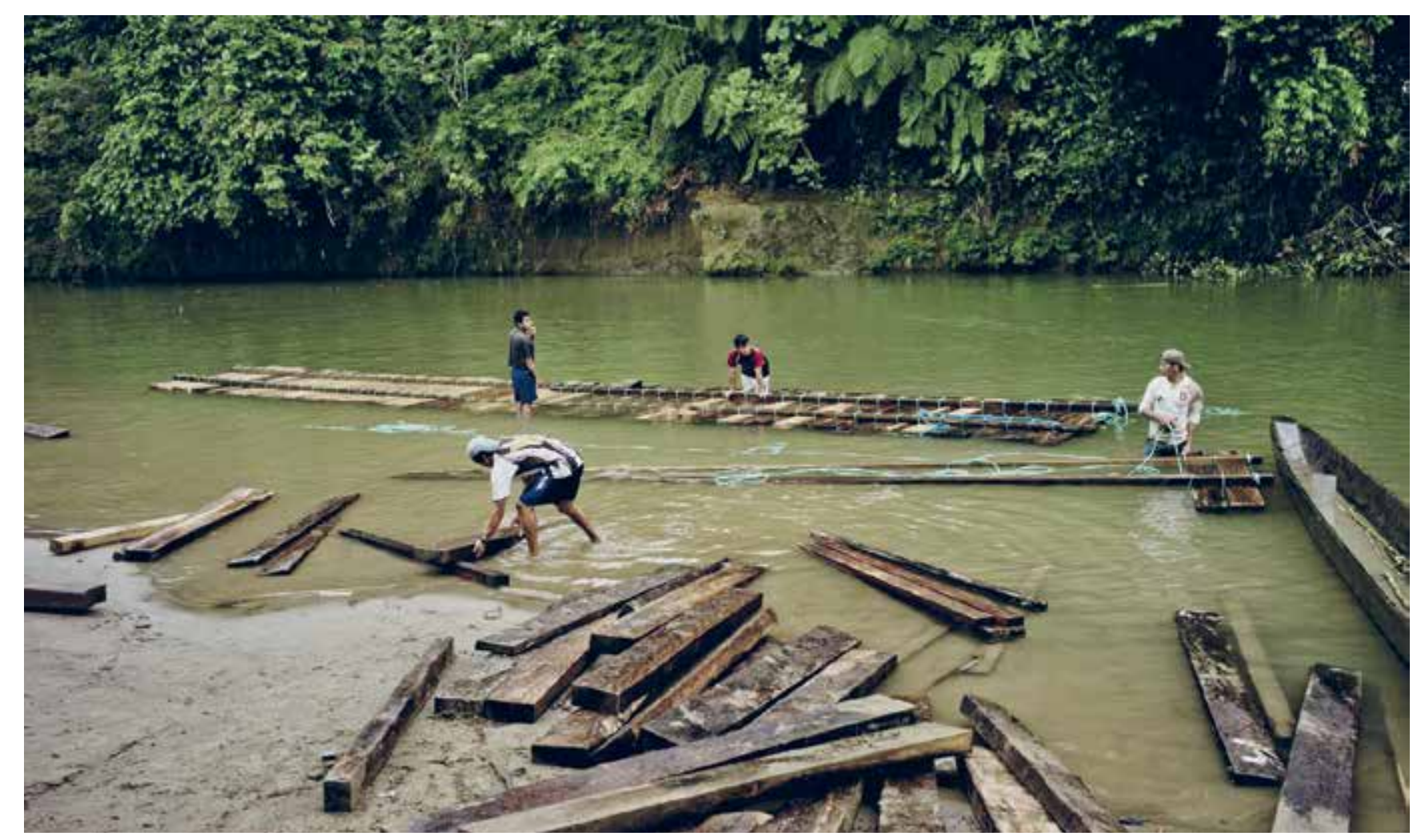

Sawn wood is prepared for transport, Ecuador

Photo by Elena Mejía, CIFOR

Better economic incentives are needed, through providing cheap credit in support of forest management, aimed at facilitating either the adoption or development of specific production systems that combine agricultural crop production, agroforestry systems and timber extraction. The incentives should encourage all users to play a role in the replacement of species that can be later used as commercial timber. Special attention should be paid to hardwood species. Both small- and large-scale plantations must encourage the regeneration of these species. As reported by interviews held during this research, adequate biophysical and silvicultural information on commercial tropical timber species is still needed to complement economic incentives.

\section{Conclusions}

Ecuador has made significant efforts to improve governance conditions in the domestic timber sector. It has simplified forestry regulations and allowed the use of simplified permits. It has also implemented a robust and relatively sophisticated system for verification of forest legality, accompanied by controls in the different stages of the timber supply chain.

Unlike other countries, Ecuador does not penalize timber harvesting with chain saws. In addition, monitoring is complemented by payments for conservation and incentives for forest regeneration and timber plantations. These efforts have been decisive in advancing toward improved forestry governance, yet better options are still needed to reduce informal logging and improve the benefits that smallholders can obtain from using their forests.

Rather than focusing on control mechanisms, forest policy should provide differentiated incentives for promoting sustainable forest management. Farmers need various forms of incentives in order for them to comply with forestry regulations. For instance, regulations should acknowledge harvesting frequency and mobilized volumes that better fit small-scale operations; fees should be charged according to actor-specific criteria, and incentives should be provided that adapt to more flexible land and forest management systems.

Our findings suggest that the main factor preventing formalization is the inability of farmers to pay not only for legal permits but also for the costs associated with undertaking a management plan. In many cases, farmers prefer to remain informal in order to have flexibility in terms of species selection and harvesting volumes, while they have to accept higher cutting volumes when working with middlemen who can afford larger harvesting operations. Thus, there is a need for a financial mechanism, with flexible conditions, that can support smallholders' and communities' access to credit on more favorable terms. 


\section{References}

Mejía E and Pacheco P. 2014. Forest use and timber markets in the Ecuadorian Amazon. Occasional Paper 111. Bogor, Indonesia: Center for International Forestry Research. [Spanish version also available: Mejía E and Pacheco P. 2013. Aprovechamiento forestal y mercados de la madera en la Amazonía Ecuatoriana. Occasional Paper 97. Bogor, Indonesia: Center for International Forestry Research].

Palacios W. 2008. Análisis de la situación de la gobernabilidad y del cumplimiento de la legislación en el sector forestal en el Ecuador (Analysis of the situation of governance and legality compliance in the forest sector in Ecuador). Quito: Aplicación de la Legislación Forestal en la Amazonía (ALFA)/Organización del Tratado de Cooperación Amazónica (OTCA)/Ministry of Environment of Ecuador (MAE).

Palacios W and Malessa U. 2010. Situación de las comunidades productoras forestales de la Amazonía ecuatoriana: obstáculos y oportunidades para comercializar madera legal (Situation of community forestry in the Ecuadorian Amazon: Barriers and opportunities to marketing legal timber). Quito: TRAFFIC.

\section{Additional reading}

Kishor $\mathrm{N}$ and Lescuyer G. 2012. Controlling illegal logging in domestic and international markets by harnessing multilevel governance opportunities. International Journal of the Commons 6(2):255-70.

Putzel L, Kelly A, Cerutti PO and Artati Y. 2014. Formalization of natural resource access and trade: Insights from land tenure, mining, fisheries, and non-timber forest products. Bogor, Indonesia: Center for International Forestry Research.

Wit M, van Dam J, Cerutti PO, Lescuyer G, Kerrett R and Parker Mckeon J. 2011. Chainsaw milling: Supplier to local markets - A synthesis. In Wit M and van Dam J, eds. Chainsaw milling: Supplier to local markets. Wageningen, the Netherlands: Tropenbos International. VII-XXII.

The EU-funded project Pro-Formal (EuropeAid/ENV/2010-242904/TPS) was implemented by the Center for International Forestry Research (CIFOR) in three regions (Southeast Asia, sub-Saharan Africa and Latin America) and five countries (Indonesia, Cameroon, the Democratic Republic of the Congo, Ecuador and Gabon) from July 2010 to December 2013. The project has been implemented with several key partners, and some outputs have already been disseminated through CIFOR's occasional papers, infobriefs, scientific journal articles and other web-based materials (available on the project website: www.cifor.org/pro-formal).

\begin{tabular}{|l|ll|} 
& $\begin{array}{l}\text { This research was carried out by CIFOR as part of the CGIAR Research Program on Forests, Trees and } \\
\text { RESEARCH }\end{array}$ & Agroforestry (CRP-FTA). This collaborative program aims to enhance the management and use of \\
PROGRAM ON & Forests, Trees and & forests, agroforestry and tree genetic resources across the landscape from forests to farms. CIFOR \\
leads CRP-FTA in partnership with Bioversity International, CATIE, CIRAD, the International Center for \\
Tropical Agriculture and the World Agroforestry Centre.
\end{tabular}
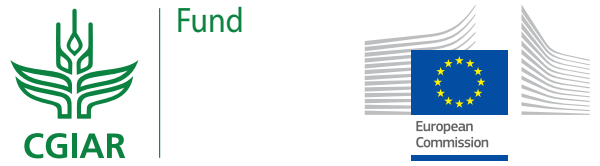